\title{
Suppression of Ethylene Responses Through Application of 1-Methylcyclopropene: A Powerful Tool for Elucidating Ripening and Senescence Mechanisms in Climacteric and Nonclimacteric Fruits and Vegetables
}

\author{
Donald J. Huber ${ }^{1}$ \\ Horticultural Sciences Department, Institute of Food and Agricultural Sciences, University of Florida, \\ P.O. Box 110690, 1213 Fifield Hall, Gainesville, FL 32611-0690
}

Additional index words. apple, avocado, banana, cantaloupe, cyclic olefin, firmness, grape, 1-methylcyclopropene, softening, strawberry, watermelon, water soaking

\begin{abstract}
The discovery of 1-methylcyclopropene (1-MCP) as an inhibitor of ethylene action has provided yet another effective tool for understanding the role of this hormone in the development of higher plants. In the nearly 12 years since the description of the effects of this growth regulator on ethylene action, the subsequent introduction of stable formulations has resulted in an explosive increase in 1-MCP-targeted research, particularly, although not exclusively, in the discipline of postharvest science. The vicinal relationship between 1-MCP and postharvest biology is understandable in view of the established roles of ethylene, both beneficial and detrimental, in the handling and storage behaviors of a vast majority of harvested fruit and vegetative organs. The use of 1-MCP is proving to be supplemental to molecular approaches for identifying and understanding the spectrum of senescence and ripening processes under the direct control of ethylene perception. Climacteric fruits have served as the predominant target for investigations of 1-MCP, and the responses of these fruits have confirmed that the antagonist operates in opposition to ethylene. Studies of nonclimacteric fruits challenged with 1-MCP and other ethylene action inhibitors have identified both ethylene-dependent and ethylene-independent ripening processes and have posed interesting questions regarding the canonical distinctions between climacteric and nonclimacteric fruits.
\end{abstract}

Nearly 12 years have passed since the discovery of 1-methylcyclopropene (1-MCP) as a specific inhibitor of ethylene action (Serek et al., 1994). Preceded in use by silver ion (Beyer, 1976), the anionic silver complex, silver thiosulfate (STS) (Veen and van der Geijn, 1978), and the cyclic olefins, 2,5-norbornadiene (Sisler et al., 1985) and diazocyclopentadiene (DACP) (Sisler and Blankenship 1993), 1-MCP presents the advantages of high efficacy at relatively low concentrations and short exposure periods for prolonged periods after a single exposure and low phytotoxicity (Sisler, 2006). The development of stable, easily applied formulations of the chemical (Daly and Kourelis, 2000) was arguably a major factor in the widespread emergence of 1-MCP research. As gases under physiological conditions, cyclic olefins including 1-MCP offer the possibility of facile, uniform delivery to even bulky fruit organs. The capacity for uniform delivery of 1-MCP to intact organs constitutes a major advantage over STS that required vascular access for uniform delivery, limiting its use to cut flowers (Veen, 1983) and, in a few instances, to intact fruits (Atta-Aly et al., 1987; Iannetta et al., 2006; Perkins-Veazie et al., 1996). Although other cyclopropenes exert more persistent antagonism of ethylene action than the methyl derivative (Buanong et al., 2005; Kebenei et al., 2003; Sisler et al., 2001, 2003), for ease of use, 1-MCP remains the cyclopropene of choice for suppressing ethylene responses (Sisler, 2006). Clearly, 1-MCP has provided postharvest scientists

${ }^{1}$ To whom correspondence should be addressed; e-mail djhuber@ufl.edu with a powerful and versatile means of probing the diverse roles of ethylene during ripening and senescence of harvested fruits and vegetables (Blankenship and Dole, 2003; Watkins, 2006).

A number of thorough reviews addressing the effects of 1-MCP on harvested fruits and vegetables have appeared in recent years (Blankenship and Dole, 2003; Lurie, 2005a, 2005b; Watkins, 2006), including one addressing specifically the effects of 1-MCP on fruit softening (Huber et al., 2003). A well-maintained and comprehensive literature base for responses of horticultural crops to $1-\mathrm{MCP}$ is also available (Watkins and Miller, 2005). Accordingly, this article takes a selective course, focusing on 1-MCP responses in ripening-initiated fruits, nonclimacteric fruits and vegetables, and features of recovery from the effects of the ethylene inhibitor.

A perusal of recent literature reveals that climacteric fruit continue to serve as the favored target for investigations of ethylene action suppression through use of 1-MCP (do Nascimento et al., 2006; Ergun et al., 2005a; Li et al., 2006; Mattheis et al., 2005; Menniti et al., 2006; Ortiz et al., 2005; Wang et al., 2006; Zhang et al., 2006). This is not unanticipated in view of the obligatory requirement of ethylene for the initiation and completion of normal ripening in climacteric fruit (Klee, 2004; Lelièvre et al., 1997). Notable responses of climacteric fruits include altered ethylene production and respiration (Ergun et al., 2005b; Golding et al., 1998; Ortiz et al., 2006; Zhang et al., 2006), delayed or suppressed softening (Adkins et al., 2005; Ergun et al., 2005b; Liguori et al., 2004; Menniti et al., 2006; Salvador et al., 2006;
Sane et al., 2005; Toivonen and Lu, 2005; Watkins and Nock, 2005), and altered or delayed volatile emissions (Defilippi et al., 2005; El-Sharkawy et al., 2005; Li et al., 2006; Mattheis et al., 2005; Pre-Aymard et al., 2005; Rizzolo et al., 2005). Evident from these and other studies is that there are no cases in which climacteric fruits have not responded significantly and dramatically to 1-MCP.

The use of 1-MCP has demonstrated that all of the primary features of ripening in climacteric fruit, including volatile production, softening, and pigment changes, are inexorably linked to competent ethylene perception and signal transduction (AdamsPhillips et al., 2004; Lelièvre et al., 1997). Consistent with heightened ethylene sensitivity in ripening competent, preclimacteric fruit (Klee, 2004), more extreme responses to ethylene action suppression have been noted before the onset of ripening. As shown for guava (Psidium guineense Sw.) (Bassetto et al., 2005), tomato (Solanum lycopersicum L.) (Hurr et al., 2005), and banana (Musa sp.) (Bagnato et al., 2003; Pelayo et al., 2003) fruits, application of 1-MCP, particularly at higher concentrations, to preripe fruit can result in complete inhibition of or severely compromised patterns of ripening. The inherently limited ripening capacity of immature tomato fruit is further exacerbated in response to 1-MCP (Hurr et al., 2005). Banana fruit subjected to high concentrations of 1-MCP (Bagnato et al., 2003; Pelayo et al., 2003) or when preclimacteric (Golding et al., 1998) show abnormal skin degreening, a condition circumvented to some degree using ripening-initiated fruit exposed to moderate levels of the antagonist (Bagnato et al., 2003). It seems likely that global recovery 
of most ripening parameters and, consequently, attainment and maintenance of optimum quality will be best achieved in instances when 1-MCP is applied after ripening initiation. Apple [Malus sylvestris L. (Mill.) var. domestica Borkh. Mansf.] appears to represent an exception to this view in that the goals of long-term storage and maintenance of firm, crisp texture in many cultivars is best achieved when 1-MCP is applied before ripening (Watkins, 2006).

That suppression of ethylene preception will interrupt the progression of ripening and senescence once initiated was first demonstrated using STS and DACP in both fruit and floral organs (Peiser, 1989; Smith et al., 1989; Tucker and Brady, 1987) and has been definitively confirmed with studies using 1-MCP. Application of 1-MCP to tomato fruit at progressively advanced stages of ripening effectively decelerated softening and red color development (Hoeberichts et al., 2002; Hurr et al., 2005) and strongly suppressed midclimacteric ethylene production when applied to turning, pink, and ripe fruit (Hoeberichts et al., 2002; Nakatsuka et al., 1997, 1998). 1-MCP-mediated suppression of ethylene production in midclimacteric tomato was accompanied by sharp declines in transcript abundance for 1-aminocyclopropane-1-carboxylic acid (ACC) oxidases (ACO) ( $L E-A C O 1$ and $L E-A C O 4$ ) and (ACC) synthases ( $L E-A C S 2$ and $L E-A C S 4$ ) (Nakatsuka et al., 1998). Transcript abundance for expansin 1 (EXP1), a wall-localized protein capable of destabilizing bonding between matrix polysaccharides (Cosgrove, 2000), and phytoene synthase 1 (PSY1), a carotenoid biosynthesis enzyme (Fray and Grierson, 1993), also declined significantly in ripening fruit treated with 1-MCP $\left(150 \mu \mathrm{L} \cdot \mathrm{L}^{-1}\right)$ (Hoeberichts et al., 2002). Although Nakatsuka et al. (1998) did not address specifically the effects on fruit physical parameters (color, firmness, and so on), noteworthy is their observation that the significant and dramatic modulation in gene expression in both preclimacteric and midclimacteric fruit was attained using 1-MCP concentrations as low as 10 to $20 \mathrm{~nL} \cdot \mathrm{L}^{-1}$.

The capacity of 1-MCP to interrupt the progression of ripening, once initiated, varies among different fruits and with the ripening parameters selected for study. Softening of avocado (Persea americana Mill.) was recalcitrant to $1-\mathrm{MCP}\left(500 \mathrm{~nL} \cdot \mathrm{L}^{-1}, 18 \mathrm{~h}\right)$ applied beyond $48 \mathrm{~h}$ after ripening initiation (Adkins et al., 2005), whereas the abundance of ethylene biosynthesis and receptor transcripts PA-ACS1 (Persea americana ACC synthase), $P A-A C O$ (ACC oxidase), and PA-ERS1 (ethylene response sensor) mRNAs declined to nearly trace levels within $2 \mathrm{~d}$ of 1-MCP application (Owino et al., 2002). Discontinuing 1-MCP treatment was followed within $2 \mathrm{~d}$ by hyperinduction of $P A-A C S 1, P A-A C O$, and $P A-E R S 1$ transcripts. The effects of 1-MCP $\left(45 \mu \mathrm{L} \cdot \mathrm{L}^{-1}\right)$ on several ripening parameters in banana fruit were significantly diminished when applied $24 \mathrm{~h}$ after initiation of ripening (Golding et al., 1998) and eliminated if delayed 3 or $5 \mathrm{~d}$ (Jiang et al., 1999).
Data from Golding et al. (1998) are striking in that differences in skin color, volatile production, and climacteric ethylene and $\mathrm{CO}_{2}$ production in response to 1-MCP exposure either 6 or $12 \mathrm{~h}$ after ripening initiation persisted through the $30+\mathrm{d}$ required to reach the postclimacteric phase. This indicates that despite the global recovery from the effects of 1-MCP, the consequences of suppressing ethylene responses during early ripening can persist for prolonged periods. 1-MCP was also effective at suppressing softening, electrolyte leakage, and delaying overripening when applied to ripe papaya (Carica papaya L.) (Ergun and Huber, 2004) and 'Galia' melon (Cucumis melo var. reticulatus L.) (Ergun et al., 2005a) fruits. Softening of apple fruit exposed to 1-MCP after initiation of the climacteric was strongly suppressed, and more persistent effects were obtained with multiple applications of the inhibitor (Mir et al., 2001). The variability in responses of several cultivars of apple to 1-MCP, applied at harvest or after periods of delay, was attributed in part to whether the climacteric was initiated (Watkins and Nock, 2005).

Suppression of ethylene action using 1-MCP has lent support to results from molecular studies indicating that ethylene dependency of some ripening processes changes during ripening. Selected studies of banana (Zhang et al., 2006), papaya (Ergun and Huber, 2004), tomato (Hoeberichts et al., 2002), and 'Booth 7' avocado (Jeong and Huber, 2004; Jeong et al., 2003) reveal that softening is unaltered relative to controls in the short term (several days) after 1-MCP treatment but becomes increasingly suppressed as ripening proceeds. Although the apparent increasing suppression of softening with ripening could reflect a delay in the ability of 1-MCP to engage and affect signal output of ethylene receptors, or the time required for depletion of preexisting pools of specific enzymes and transcripts, molecular studies are supportive of the idea that ethylene dependency of softening in some fruits does change during the course of ripening. Analysis of softening of ACO-antisense 'Charentais' melons (Cucumis melo var. cantalupensis) in response to increasing dosages of ethylene revealed both ethylenedependent and -independent components (Flores et al., 2001a, 2001b). 'Galia' melon (Cucumis melo L.) expressing an antisense ACO construct and exhibiting strongly suppressed ethylene production softened normally through the half-slip stage, thereafter remaining significantly firmer than wild-type lines (Nuñez-Palenius et al., 2007). Similarly, softening of ACO (EFE)-antisense tomato fruit was significantly more impaired during the later stages of ripening (Murray et al., 1993). Softening of papaya (Ergun and Huber, 2004) and 'Galia' melon (Ergun et al., 2005a) treated with 1-MCP was proportionally more impaired during the late stages of ripening. Detailed genomic analysis of the temporal sequence of softening of peach fruit has demonstrated participation of ethylenedependent (both upregulated and downregu- lated) and ethylene-independent enzymes and structural proteins, with ethylene-independent events prevailing in the early period of ripening (Trainotti et al., 2003).

In most every case, the recovery of physical and gene expression ripening responses in climacteric fruits after 1-MCP treatment can be circumvented by additional exposures to the ethylene antagonist (Hoeberichts et al., 2002; Jayanty et al., 2004; Mathooko et al., 2001; Mir et al., 2004; Toivonen and Lu, 2005). These observations are consistent with the strong upregulation of ethylene receptor transcription and translation during the climacteric (Czarny et al., 2006; Klee, 2004), and also suggest that 1-MCP receptor binding might be reversible (Jayanty et al., 2004). Apple fruit, with their potential for comparatively long storage periods over a range of temperatures, have proven useful for analysis of long-term effects of and recovery from 1-MCP exposure. In 'RedChief Delicious' apples subjected to $1-\mathrm{MCP}\left(0.7 \mu \mathrm{L} \cdot \mathrm{L}^{-1}\right)$ at frequencies ranging from single (once per year) to once per week, the advantages of weekly exposure, assessed from firmness retention, were evident during extended storage at higher temperatures (Mir et al., 2001). The observation that 'RedChief Delicious' apple fruit receiving subsaturating dosages $\left(0.1 \mu \mathrm{L} \cdot \mathrm{L}^{-1}\right)$ of 1-MCP applied weekly were unable to maintain firmness to the extent achieved at higher levels $\left(1.0 \mu \mathrm{L} \cdot \mathrm{L}^{-1}\right)$ after $\approx 100 \mathrm{~d}$ in store was interpreted as evidence for a dissociation of 1-MCP from the ethylene receptor (Jayanty et al., 2004). Extendedchain cyclopropenes, including 1-octyl-, 1-nonyl-, and 1-decyl-derivatives, increased by nearly threefold the duration of chlorophyll retention compared with 1-MCP (Sisler et al., 2003). Assuming that these cyclopropenes act solely through direct interactions with the ethylene receptor, the differential recovery from the various derivatives lends support to the notion that cyclopropene receptor binding is reversible. As a result of the hydrophobic nature and low volatility of 1-octyl-, 1-nonyl-, and 1-decyl-cyclopropenes, however, they would appear to have properties conducive for partitioning into membranes, possibly providing an available pool to compensate for cyclopropene dissociation as well as receptor replenishment. Evidence for nonselective binding was the observation that 1-MCP partitioned in much higher amounts and at faster rates in the lipidrich avocado compared with apple fruit (Dauny et al., 2003). The accumulation of internal ethylene during long-term storage (Watkins and Nock, 2005) might also contribute to the dissipation of 1-MCP responses. The effect of 1-MCP $\left(1.0 \mu \mathrm{L} \cdot \mathrm{L}^{-1}\right)$ at suppressing ripening of tomato fruit, for example, is abolished if applied simultaneously with ethylene at $50.0 \mu \mathrm{L} \cdot \mathrm{L}^{-1}$ (Jeong and Huber, unpublished data). Notwithstanding the clear evidence that multiple applications of 1-MCP are more effective at suppressing ripening in general, even single applications resulted in near total suppression of polygalacturonase activity ( $24 \mathrm{~d}$ ) in avocado fruit 
(Jeong and Huber, 2004) and both $\beta$-amylase activity and protein $(28 \mathrm{~d})$ accumulation in banana fruit (do Nascimento et al., 2006), the inhibition persisting through the duration of the ethylene climacteric. Persimmon (Diospyros kaki Thunb.) fruit treated with 1MCP showed only a transient delay in polygalacturonase activity but acute suppression of pectinmethylesterase and $\beta$-galactosidase activities (Ortiz et al., 2005). Treatment of avocado fruit with ethylene $\left(100 \mu \mathrm{L} \cdot \mathrm{L}^{-1}, 24 \mathrm{~h}\right)$ at periods of up to $14 \mathrm{~d}$ after 1-MCP exposure did not influence time to soften (Adkins et al., 2005). Interestingly, the response of 1-MCPtreated banana fruit to subsequent ethylene exposure increased with delay between exposures to the two gases (Jiang et al., 1999), but the response was independent of ethylene concentrations from 0.1 to $100 \mu \mathrm{L} \cdot \mathrm{L}^{-1}$.

$1-\mathrm{MCP}$ has been of immense value for detailing the diverse roles of endogenous and exogenous ethylene in the postharvest metabolism of fruits and vegetables exhibiting nonclimacteric ripening and senescence patterns. Responses of nonclimacteric fruit and vegetative organs to $1-\mathrm{MCP}$ include delayed chlorophyll and protein degradation in coriander (Coriandrum sativum L.) (Jiang et al., 2002) and parsley (Petroselinum crispum Mill.) (Ella et al., 2003); delayed yellowing of broccoli (Brassica oleracea L.) (Fan and Mattheis, 2000b; Forney et al., 2003) and rocket leaves (Eruca sativa Mill.) (Koukounaras et al., 2006); firmness retention in cucumber (Cucumis sativus L.) (Lima et al., 2005) and watermelon (Citrullus lanatus Thunb. Matsum and Nakai) (Mao et al., 2004); delayed vivipary in chayote (Sechium edule) (Cadena-Iniguez et al., 2006); suppressed pigment accumulation and softening of strawberry (Fragaria $\times$ ananassa Duch.) (Jiang et al., 2001); suppressed degreening of 'Shamouti' orange (Citrus sinensis L.) (Porat et al., 1999), grapefruit (Citrus paradisi) (McCollum and Maul, 2007), and 'Tahiti' lime (Citrus latifolia Yu. Tanaka) (Jomori et al., 2003); reduced disorders in carrot (Daucus carota L.) (Fan and Mattheis, 2000a) and 'Iceberg' lettuce (Lactuca sativa L.) (Fan and Mattheis, 2000a); and delayed lignin deposition and firmness increases in loquat (Eriobotrya japonica Lindl.) (Cai et al., 2006a, 2006b). In general, the effects of 1-MCP on nonclimacterics are dramatically more evident when these commodities are exposed to exogenous ethylene. In a survey of six leafy Asian vegetables, for example, only mizuna (Brassica rapa var. nipposinica) and tatsoi (Brassica rapa var. rosularis) benefitted from 1-MCP treatment when subsequently stored in an ethylene-free environment (Able et al., 2003). Nevertheless, because ambient ethylene levels in retail settings are often sufficient to affect significant reductions in postharvest shelf life (Wills et al., 1999, 2000), 1-MCP perhaps has some potential for application to highvalue nonclimacteric commodities with lowthreshold ethylene sensitivity.

Features of ethylene biosynthesis in vegetative and other nonclimacteric organs are consistent with system 1 , negative feedback regulation (Kende, 1993; McMurchie et al., 1972). Accordingly, both coriander (Jiang et al., 2002) and parsley (Ella et al., 2003) showed significantly enhanced ethylene production in the short term after 1-MCP exposure. Particularly noteworthy are parsley (Ella et al., 2003) and 'Marsh' grapefruit (McCollum and Maul, 2007) that, in response to $1-\mathrm{MCP}\left(10 \mu \mathrm{L} \cdot \mathrm{L}^{-1}\right.$ parsley, $300 \mathrm{~nL} \cdot \mathrm{L}^{-1}$ grapefruit), exhibited hyperproduction of ethylene to levels as high as 20 and 50 $\mu \mathrm{L} \cdot \mathrm{kg}^{-1} \cdot \mathrm{h}^{-1}$, respectively.

1-MCP studies with grape (Vitis vinifera L.) and strawberry have confirmed and extended our understanding of the role of endogenous ethylene in the development and ripening of these paradigmatic nonclimacteric fruits (Rhodes, 1980). Ethephon has long been known to promote the maturation and coloration of grapes (Weaver and Montgomery, 1974), and ACC or STS, respectively, either accelerated or suppressed growth and red color development in strawberry fruit (Perkins-Veazie et al., 1996). Application of 1-MCP to attached grapes at weekly intervals after bloom strongly reduced final berry diameter and anthocyanin levels (Chervin et al., 2004). Furthermore, the responses to 1-MCP were dependent on stage of berry development with the maximum response temporally associated with and reciprocal to internal ethylene levels, which followed a climacteric-like accumulation pattern. The expression of alcohol dehydrogenease $(V v A D H 2)$ during grape berry ripening was inhibited in response to $1-\mathrm{MCP}$ treatment of attached grape clusters (Tesniere et al., 2004) as was the accumulation of sucrose and mRNA of two sucrose transporters (SUC11 and SUC12) (Chervin et al., 2006). Applied to harvested, ripe grapes, 1-MCP suppressed ethylene production, enhanced losses in terpenols and esters, and delayed loss in anthocyanins (Bellincontro et al., 2006). The responses of harvested, ripe strawberry fruit to 1-MCP include suppression of softening and anthocyanin accumulation (Jiang et al., 2001), decreased ethylene production (Bower et al., 2003; Jiang et al., 2001), and higher incidence of decay (Bower et al., 2003; Jiang et al., 2001; Ku et al., 1999). Although the effects of 1-MCP on strawberry physical attributes (firmness, color) are for the most part unremarkable, a significant effect on the expression (upregulated or downregulated in response to 1-MCP) of a number of genes strongly suggests that ethylene-dependent processes operate during both growth and ripening (Balogh et al., 2005). Analysis of strawberry fruit in planta demonstrated a distinct and significant rise in ethylene and $\mathrm{CO}_{2}$ production coincident with the transition from pink through red, and ethylene production in response to STS applied through the pedicel vasculature of fruit at progressively more advanced stages of development responded in a manner indicative of a transition from system 1 regulation (STS stimulated ethylene production) during early growth and expan- sion to system 2 regulation (STS suppressed ethylene production) during ripening (Iannetta et al., 2006). This report is supported by other studies in which 1-MCP application decreased the ethylene production of harvested ripe strawberry fruit (Bower et al., 2003; Jiang et al., 2001). Ripening strawberry fruit contain type 1 (FaEtrl, FaErs 1) and type 2 (FaEtr2) ethylene receptor genes, the expression of which increase or persist as fruit ripen (Trainotti et al., 2005).

The responses of strawberry and grape fruits to ethylene and ethylene suppression contrast sharply with those reported for other nonclimacteric fruits, including cucumber and watermelon. Both cucumber (Cucumis sativus L.) (Lima et al., 2005) and watermelon (Citrullus lanatus Thunb. Matsum and Nakai) (Mao et al., 2004) fruits within days of exposure to ethylene exhibit accelerated softening and acute water soaking. In the case of watermelon, which can be adversely influenced by ethylene regardless of stage of maturation (Karakurt and Huber, 2004), exposure to ethylene induces significant increases in electrolyte efflux, juice leakage, lipase and LOX activities, and phospholipid catabolism (Mao et al., 2004). A single exposure to 1-MCP afforded complete protection from the effects of continuous ethylene for up to 8 (watermelon) or $16 \mathrm{~d}$ (cucumber). That cucumber and watermelon retain a capacity to respond acutely to ethylene is intriguing. Some semblance of climacteric behavior might have been expressed in progenitors of these highly domesticated fruit, having been outselected in efforts to improve storage properties.

1-MCP has proven useful for elucidating changes in ethylene-dependent and ethyleneindependent events occurring in response to tissue wounding. Treatment with 1-MCP before wounding of mature green rin and wild-type tomato resulted in a $50 \%$ reduction in wound-induced ethylene production but did not affect wound-enhanced expression of LE-ACS2 (Lycopersicon esculentum ACC synthase 1), LE-ACS-6 (ACC synthase 6), and $L E-A C O 1$ (ACC oxidase 1) (Yokotani et al., 2004). Expression of ripening-related $L E-A C O 1$ and $L E-A C S 2$ genes, however, were arrested in intact (nonwounded) tomato fruit after 1-MCP treatment (Hoeberichts et al., 2002; Nakatsuka et al., 1997), indicating that wound-induced events operate to some extent independently of ethylene signaling. In contrast to tomato, 1-MCP significantly enhanced wound-induced ethylene synthesis and PC-ACS2 mRNA levels in preclimacteric avocado fruit (Owino et al., 2002) and ethylene biosynthesis and accumulation of PP-ACS1 in peach (Mathooko et al., 2001) fruit. Independent wound and ethylene signaling was also evident in studies of intact and fresh-cut lettuce. 1-MCP treatment $(0.5 \mu \mathrm{L} \cdot \mathrm{L}, 3 \mathrm{~h})$ inhibited ethyleneinduced phenol accumulation in whole heads of 'Iceberg' lettuce but did not prevent accumulation in fresh-cut (wounded) product (Saltveit, 2004). Consistent with the influence of wounding at overriding components 
of ethylene signaling, it is evident that the benefits conferred on treatment of whole fruit with 1-MCP are considerably dampened in fresh-cut tissues (Calderon-Lopez et al., 2005; Ergun et al., 2006a, 2007; Mao et al., 2006, 2007).

Interruption of ethylene receptor interactions and downstream signal output through applications of 1-MCP has revealed a broad array of responses in horticultural crops. This is not unexpected. Edible fruits and vegetables represent a highly diverse group in terms of both inherent physiology and in morphological derivation. Although it is tempting to speculate that tissue-specific ethylene receptor characteristics might contribute to 1-MCP response variation, binding studies do not envision differential receptor selectivity for 1-MCP and ethylene (Binder and Bleecker, 2003; Hall et al., 2000). Analysis of yeastexpressed receptor proteins from Arabidopsis [Arabidopsis thaliana (L.) Heynh] and tomato fruit has provided no evidence of differences in ethylene binding or dissociation kinetics between the receptor subtypes (O’Malley et al., 2005), a noteworthy observation in view of the fact that responses to ethylene in Arabidopsis alone can occur over $10^{7}$ orders of magnitude in ethylene concentration (Binder et al., 2004; Chen and Bleecker, 1995). Even so, the responses of Arabidopsis mutants deficient in one or more ethylene receptors has revealed that quantitative compensation in functional receptor abundance is not accompanied by a parallel compensation in ethylene responses (O'Malley et al., 2005). Indeed, detailed molecular analyses of the nonripening Green-Ripe (GR) tomato mutant have led to suggestions that the ethylene responsiveness or signaling of individual receptors with differential spatial distribution might be modulated by $G R$ and other, as yet undiscovered, proteins (Barry and Giovannoni, 2006).

The availability of ethylene action inhibitors in general and 1-MCP in particular has indeed provided a powerful tool for investigating the spectrum of ethylene effects in postharvest biology. The responses of horticultural crops to 1-MCP are impressively complex and varied, demonstrating both known as well as previously unrecognized responses to ethylene. Although at this writing, the chemical is used commercially with but a few crops, it has potential for broader application. A more thorough understanding of the variables controlling the responses to 1-MCP application will be required before it can be adopted routinely for harvested commodities. The importance of maturity, cultivar, and exposure variables (time, temperature, concentration) are complex and continue to be the focus of much research (Watkins, 2006). Of equal importance will be understanding the factors limiting the capacity of some commodities after 1-MCP treatment to engage fully the entire spectrum of developmental changes essential for expressing optimum quality. Irreversibility of 1-MCP effects is perhaps not problematic for the nonclimacterics in which arrested postharvest development and suppression of ethylene effects has no overt effect on commodity quality. The benefits of 1-MCP application with other fruits, notably the climacterics, may be in imparting the flexibility for more extended "on-vine" development followed by scheduled exposure to $1-\mathrm{MCP}$ and timely, predictable recovery in marketing channels. Other possible applications might be realized for fruits of exceptionally high perishability as a result of rapid ripening or those intolerant of lowtemperature storage. Clearly, the widespread adoption of these practices will involve consideration of both commodity and economic issues.

\section{Literature Cited}

Able, A.J., L.S. Wong, A. Prasad, and T.J. O'Hare. 2003. The effects of 1-methylcyclopropene on the shelf life of minimally processed leafy Asian vegetables. Postharvest Biol. Technol. 27:157-161.

Adams-Phillips, L., C. Barry, and J. Giovannoni. 2004. Signal transduction systems regulating fruit ripening. Trends Plant Sci. 9:331338.

Adkins, M.F., P.J. Hofman, B.A. Stubbings, and A.J. Macnish. 2005. Manipulating avocado fruit ripening with 1-methylcyclopropene. Postharvest Biol. Technol. 35:33-42.

Atta-Aly, M.A., M.E. Saltveit, Jr., and G.E. Hobson. 1987. Effect of silver ions on ethylene biosynthesis by tomato fruit tissue. Plant Physiol. 83:44-48.

Bagnato, N., R. Barrett, M. Sedgley, and A. Klieber 2003. The effects on the quality of Cavendish bananas, which have been treated with ethylene, of exposure to 1-methylcyclopropene. Inter. J. Food Sci. Technol. 38:745-750.

Balogh, A., T. Koncz, V. Tisza, E. Kiss, and L. Heszky. 2005. The effect of 1-MCP on the expression of several ripening-related genes in strawberries. HortScience 40:2088-2090.

Barry, C.S. and J.J. Giovannoni. 2006. Ripening in the tomato green-ripe mutant is inhibited by ectopic expression of a protein that disrupts ethylene signaling. Proc. Natl. Acad. Sci. 103:7923-7928.

Bassetto, E., A.P. Jacomino, A.L. Pinheiro, and R.A. Kluge. 2005. Delay of ripening of 'Pedro Sato' guava with 1-methylcyclopropene. Postharvest Biol. Technol. 35:303-308.

Bellincontro, A., A. Fardelli, D. De Santis, R. Botondi, and F. Mencarelli. 2006. Postharvest ethylene and 1-MCP treatments both affect phenols, anthocyanins, and aromatic quality of Aleatico grapes and wine. Aust. J. Grape Wine Res. 12:141-149.

Beyer, E., Jr. 1976. A potent inhibitor of ethylene action in plants. Plant Physiol. 58:268-271.

Binder, B.M. and A.B. Bleecker. 2003. A model for ethylene receptor function and 1-Methylcyclopropene action. Acta Hort. 628:177-187.

Binder, B.M., L.A. Mortimore, A.N. Stepanova, J.R. Ecker, and A.B. Bleecker. 2004. Short-term growth responses to ethylene in Arabidopsis seedlings are EIN3/EIL1 independent. Plant Physiol. 136:2921-2927.

Blankenship, S.M. and J.M. Dole. 2003. 1-Methylcyclopropene: A review. Postharvest Biol. Technol. 28:1-25.

Bower, J.H., W.V. Biasi, and E.J. Mitcham. 2003. Effects of ethylene and 1-MCP on the quality and storage life of strawberries. Postharvest Biol. Technol. 28:417-423.
Buanong, M., H. Mibus, E.C. Sisler, and M. Serek. 2005. Efficacy of new inhibitors of ethylene perception in improvement of display quality of miniature potted roses (Rosa hybrida L.). Plant Growth Reg. 47:29-38.

Cadena-Iniguez, J., L. Arevalo-Galarza, L.M. Ruiz-Posadas, J.F. Aguirre-Medina, M. Soto-Hernandez, M. Luna-Cavazos, and H.A. Zavaleta-Mancera. 2006. Quality evaluation and influence of 1-MCP on Sechium edule (Jacq.) Sw. fruit during postharvest. Postharvest Biol. Technol. 40:170-176.

Cai, C., K. Chen, W. Xu, W. Zhang, X. Li, and I. Ferguson. 2006a. Effect of 1-MCP on postharvest quality of loquat fruit. Postharvest Biol. Technol. 40:155-162.

Cai, C., C. Xu, X. Li, I. Ferguson, and K. Chen. 2006b. Accumulation of lignin in relation to change in activities of lignification enzymes in loquat fruit flesh after harvest. Postharvest Biol. Technol. 40:163-169.

Calderon-Lopez, B., J.A. Bartsch, C.Y. Lee, and C.B. Watkins. 2005. Cultivar effects on quality of fresh cut apple slices from 1-methylcyclopropene (1-MCP)-treated apple fruit. J. Food Sci. 70:S221-S227.

Chen, Q.G. and A.B. Bleecker. 1995. Analysis of ethylene signal-transduction kinetics associated with seedling-growth response and chitinase induction in wild-type and mutant Arabidopsis. Plant Physiol. 108:597-607.

Chervin, C., A. El-Kereamy, J.P. Roustan, A. Latche, J. Lamon, and M. Bouzayen. 2004. Ethylene seems required for the berry development and ripening in grape, a non-climacteric fruit. Plant Sci. 167:1301-1305.

Chervin, C., N. Terrier, A. Ageorges, F. Ribes, and T. Kuapunyakoon. 2006. Influence of ethylene on sucrose accumulation in grape berry. Amer. J. Enol. Viticul. 57:511-513.

Cosgrove, D.J. 2000. Loosening of plant cell walls by expansins. Nature 407:321-326.

Czarny, J.C., V.P. Grichko, and B.R. Glick. 2006. Genetic modulation of ethylene biosynthesis and signaling in plants. Biotechnol. Adv. 24:410-419.

Daly, J. and B. Kourelis. 2000. Synthesis methods, complexes and delivery methods for the safe and convenient storage, transport and application of compounds for inhibiting the ethylene response in plants. U.S. Patent No. 6017849. 25 Jan. 2000

Dauny, P.T., D.C. Joyce, and C. Gamby. 2003. 1Methylcyclopropene influx and efflux in 'Cox' apple and 'Hass' avocado fruit. Postharvest Biol. Technol. 29:101-105.

Defilippi, B.G., A.M. Dandekar, and A.A. Kader. 2005. Relationship of ethylene biosynthesis to volatile production, related enzymes, and precursor availability in apple peel and flesh tissues. J. Agr. Food Chem. 53:3133-3141.

do Nascimento, J.R.O., A.V. Junior, P.Z. Bassinello, B.R. Cordenunsi, J.A. Mainardi, E. Purgatto, and F.M. Lajolo. 2006. Beta-amylase expression and starch degradation during banana ripening. Postharvest Biol. Technol. 40:41-47.

Ella, L., A. Zion, A. Nehemia, and L. Amnon. 2003. Effect of the ethylene action inhibitor 1methylcyclopropene on parsley leaf senescence and ethylene biosynthesis. Postharvest Biol. Technol. 30:67-74.

El-Sharkawy, I., D. Manriquez, F.B. Flores, F. Regad, M. Bouzayen, A. Latche, and J.-C. Pech. 2005. Functional characterization of a melon alcohol acyl-transferase gene family involved in the biosynthesis of ester volatiles. Identification of the crucial role of a threonine residue for enzyme activity. Plant Mol. Biol. 59:345-362. 
Ergun, M. and D.J. Huber. 2004. Suppression of ethylene perception extends shelf-life and quality of 'Sunrise Solo' papaya fruit at both pre-ripe and ripe stages of development. Europ. J. Hort. Sci. 69:184-192.

Ergun, M., D.J. Huber, J. Jeong, and J.A. Bartz. 2006a. Extended shelf life and quality of freshcut papaya derived from ripe fruit treated with the ethylene antagonist 1-methylcyclopropene. J. Amer. Soc. Hort. Sci. 131:97-103.

Ergun, M., J. Jeong, D.J. Cantliffe, and D.J. Huber. 2005a. Suppression of ripening and softening of 'Galia' melon fruit by 1-methylcyclopropene applied at pre-ripe or ripe stages of development. HortScience 40:170-175.

Ergun, M., J. Jeong, D.J. Huber, and D.J. Cantliffe. 2007. Physiology of fresh-cut 'Galia' (Cucumis melo var. reticulatus) from ripe fruit treated with 1-methylcyclopropene. Postharvest Biol. Technol. 44:286-292.

Ergun, M., S.A. Sargent, J. Crane, and D.J. Huber. $2005 \mathrm{~b}$. Ripening and quality responses of mamey sapote fruit to postharvest wax and 1methylcyclopropene treatments. Postharvest Biol. Technol. 36:127-134.

Fan, X.T. and J.P. Mattheis. 2000a. Reduction of ethylene-induced physiological disorders of carrots and 'Iceberg' lettuce by 1-methylcyclopropene. HortScience 35:1312-1314.

Fan, X.T. and J.P. Mattheis. 2000b. Yellowing of broccoli in storage is reduced by 1-methylcyclopropene. HortScience 35:885-887.

Flores, F., M. Ben-Amor, B. Jones, J.C. Pech, M. Bouzayen, A. Latche, and F. Romojaro. 2001a. The use of ethylene-suppressed lines to assess differential sensitivity to ethylene of the various ripening pathways in cantaloupe melons. Physiol. Plant. 113:128-133.

Flores, F.B., M.C. Martinez-Madrid, F.J. SanchezHidalgo, and F. Romojaro. 2001b. Differential rind and pulp ripening of transgenic antisense ACC oxidase melon. Plant Physiol. Biochem. 39:37-43.

Forney, C.F., J. Song, L.H. Fan, P.D. Hildebrand, and M.A. Jordan. 2003. Ozone and 1-methylcyclopropene alter the postharvest quality of broccoli. J. Amer. Soc. Hort. Sci. 128:403408.

Fray, R.G. and D. Grierson. 1993. Identification and genetic analysis of normal and mutant phytoene synthase genes of tomato by sequencing, complementation and co-suppression. Plant Mol. Biol. 22:589-602.

Golding, J.B., D. Shearer, S.G. Wyllie, and W.B. McGlasson. 1998. Application of 1-MCP and propylene to identify ethylene-dependent ripening processes in mature banana fruit. Postharvest Biol. Technol. 14:87-98.

Hall, A.E., J.L. Findell, G.E. Schaller, E.C. Sisler, and A.B. Bleecker. 2000. Ethylene perception by the ERS1 protein in Arabidopsis. Plant Physiol. 123:1449-1457.

Hoeberichts, F.A., L.H.W. Van Der Plas, and E.J. Woltering. 2002. Ethylene perception is required for the expression of tomato ripening-related genes and associated physiological changes even at advanced stages of ripening. Postharvest Biol. Technol. 26:125-133.

Huber, D.J., J. Jeong, and L.-C. Mao. 2003. Softening during ripening of ethylene-treated fruits in response to 1-methylcyclopropene application. Acta Hort. 628:193-202.

Hurr, B.M., J.H. Lee, and D.J. Huber. 2005. Differential responses in color changes and softening of 'Florida 47' tomato fruit treated at green and advanced ripening stages with the ethylene antagonist 1-methylcyclopropene. HortTechnology 15:617-622.
Iannetta, P.P.M., L.J. Laarhoven, N. Medina-Escobar, E.K. James, M.T. Mcmanus, H.V. Davies, and F.J.M. Harren. 2006. Ethylene and carbon dioxide production by developing strawberries show a correlative pattern that is indicative of ripening climacteric fruit. Physiol. Plant. 127:247-259.

Jayanty, S.S., M. Canoles, and R.M. Beaudry. 2004. Concentration dependence of 'Redchief Delicious' apple fruit softening and chlorophyll fluorescence to repeated doses of 1-methylcyclopropene. J. Amer. Soc. Hort. Sci. 129:760765.

Jeong, J. and D.J. Huber. 2004. Suppression of avocado (Persea americana Mill.) fruit softening, and changes in cell wall matrix polysaccharides and enzyme activities: Differential responses to 1-MCP and delayed ethylene application. J. Amer. Soc. Hort. Sci. 129:752759.

Jeong, J., D.J. Huber, and S.A. Sargent. 2003. Delay of avocado (Persea americana) fruit ripening by 1 -methylcyclopropene and wax treatments. Postharvest Biol. Technol. 28: 247-257.

Jiang, W., Q. Sheng, X. Zhou, M. Zhang, and X. Liu. 2002. Regulation of detached coriander leaf senescence by 1-methylcyclopropene and ethylene. Postharvest Biol. Technol. 26:339345.

Jiang, Y.M., D.C. Joyce, and A.J. Macnish. 1999. Responses of banana fruit to treatment with 1-methylcyclopropene. Plant Growth Reg. 28: $77-82$.

Jiang, Y.M., D.C. Joyce, and L.A. Terry. 2001. 1-methylcyclopropene treatment affects strawberry fruit decay. Postharvest Biol. Technol. 23:227-232.

Jomori, M.L.L., R.A. Kluge, and A.P. Jacomino, 2003. Cold storage of 'Tahiti' lime treated with 1-methylcyclopropene. Scientia Agr. 60: 785-788.

Karakurt, Y. and D.J. Huber. 2004. Ethyleneinduced gene expression, enzyme activities, and water soaking in immature and ripe watermelon (Citrullus lanatus) fruit. J. Plant Physiol. 161:381-388.

Kebenei, Z., E.C. Sisler, T. Winkelmann, and M. Serek. 2003. Efficacy of new inhibitors of ethylene perception in improvement of display life of kalanchoe (Kalanchoe blossfeldiana Poelln.) flowers. Postharvest Biol. Technol. 30:169-176.

Kende, H. 1993. Ethylene biosynthesis. Annu. Rev. Plant Physiol. Plant Mol. Biol. 44:283-307.

Klee, H.J. 2004. Ethylene signal transduction. Moving beyond Arabidopsis. Plant Physiol. 135:660-667.

Koukounaras, A., A.S. Siomos, and E. Sfakiotakis. 2006. 1-Methylcyclopropene prevents ethylene induced yellowing of Rocket leaves. Postharvest Biol. Technol. 41:109-111.

Ku, V.V.V., R.B.H. Wills, and S. Ben-Yehoshua. 1999. 1-Methylcyclopropene can differentially affect the postharvest life of strawberries exposed to ethylene. HortScience 34:119-120.

Lelièvre, J.-M., A. Latchè, B. Jones, M. Bouzayen, and J.-C. Pech. 1997. Ethylene and fruit ripening. Physiol. Plant. 101:727-739.

Li, D.P., Y.F. Xu, L.P. Sun, L.X. Liu, X.L. Hu, D.Q. Li, and H.R. Shu. 2006. Salicylic acid, ethephon, and methyl jasmonate enhance ester regeneration in 1-MCP-treated apple fruit after long-term cold storage. J. Agr. Food Chem. 54:3887-3895.

Liguori, G., A. Weksler, Y. Zutahi, S. Lurie, and I. Kosto. 2004. Effect of 1-methylcyclopropene on ripening of melting flesh peaches and nectarines. Postharvest Biol. Technol. 31: 263-268.

Lima, L.C.O., B.M. Hurr, and D.J. Huber. 2005. Deterioration of beit alpha and slicing cucumbers (Cucumis sativus L.) during storage in ethylene or air: Responses to suppression of ethylene perception and parallels to natural senescence. Postharvest Biol. Technol. 37: 265-276.

Lurie, S. 2005a. Regulation of ethylene biosynthesis in fruits by aminoethoxyvinylglycine and 1-methylcyclopropene. Stewart Postharvest Rev 1(3):1-8.

Lurie, S. 2005b. Application of 1-methylcyclopropene to prevent spoilage. Stewart Postharvest Rev. 1(4):1-4.

Mao, L., Y. Karakurt, and D.J. Huber. 2004. Incidence of water-soaking and phospholipid catabolism in ripe watermelon (Citrullus lanatus) fruit: Induction by ethylene and prophylactic effects of 1-methylcyclopropene. Postharvest Biol. Technol. 33:1-9.

Mao, L., G. Wang, and F. Que. 2007. Application of 1-methylcyclopropene prior to cutting reduces wound responses and maintains quality in cut kiwifruit. J. Food Eng. 78:361-365.

Mao, L.C., J. Jeong, F. Que, and D.J. Huber. 2006. Physiological properties of fresh-cut watermelon (Citrullus lanatus) in response to 1-methylcyclopropene and post-processing calcium applications. J. Sci. Food Agr. 86:46-53.

Mathooko, F.M., Y. Tsunashima, W.Z.O. Owino, Y. Kubo, and A. Inaba. 2001. Regulation of genes encoding ethylene biosynthetic enzymes in peach (Prunus persica L.) fruit by carbon dioxide and 1-methylcyclopropene. Postharvest Biol. Technol. 21:265-281.

Mattheis, J.P., X.T. Fan, and L.C. Argenta. 2005. Interactive responses of Gala apple fruit volatile production to controlled atmosphere storage and chemical inhibition of ethylene action. J. Agr. Food Chem. 53:4510-4516.

McCollum, G. and P. Maul. 2007. 1-MCP inhibits degreening but stimulates respiration and ethylene biosynthesis in grapefruit. HortScience 42:120-124.

McMurchie, E.J., W.B. McGlasson, and I.L. Eaks. 1972. Treatment of fruit with propylene gives information about the biogenesis of ethylene. Nature 237:235-236.

Menniti, A.M., I. Donati, and R. Gregori. 2006. Responses of 1-MCP application in plums stored under air and controlled atmospheres. Postharvest Biol. Technol. 39:243-246.

Mir, N., M. Canoles, R. Beaudry, E. Baldwin, and C. Pal Mehla. 2004. Inhibiting tomato ripening with 1-methylcyclopropene. J. Amer. Soc. Hort. Sci. 129:112-120.

Mir, N.A., E. Curell, N. Khan, M. Whitaker, and R.M. Beaudry. 2001. Harvest maturity, storage temperature, and 1-MCP application frequency alter firmness retention and chlorophyll fluorescence of 'Redchief Delicious' apples. J. Amer. Soc. Hort. Sci. 126:618-624.

Murray, A.G., G.E. Hobson, W. Schuch, and C.R. Bird. 1993. Reduced ethylene synthesis in EFE antisense tomatoes has differential effects on fruit ripening processes. Postharvest Biol. Technol. 2:301-313.

Nakatsuka, A., S. Murachi, H. Okunishi, S. Shiomi, R. Nakano, Y. Kubo, and A. Inaba. 1998. Differential expression and internal feedback regulation of 1-aminocyclopropane-1-carboxylate oxidase, and ethylene receptor genes in tomato fruit during development and ripening. Plant Physiol. 118:1295-1305.

Nakatsuka, A., S. Shiomi, Y. Kubo, and A. Inaba. 1997. Expression and internal feedback 
regulation of ACC synthase and ACC oxidase genes in ripening tomato fruit. Plant Cell Physiol. 38:1103-1110.

Nuñez-Palenius, H.G., D.J. Huber, H.J. Klee, and D.J. Cantliffe. 2007. Fruit ripening characteristics in a transgenic 'Galia' male parental muskmelon (Cucumis melo L. var. reticulatus Ser.) line. Postharvest Biol. Technol. 44:95-100.

O'Malley, R.C., F.I. Rodriguez, J.J. Esch, B.M. Binder, P. O'Donnell, H.J. Klee, and A.B. Bleecker. 2005. Ethylene-binding activity, gene expression levels, and receptor system output for ethylene receptor family members from Arabidopsis and tomato. Plant J. 41:651-659.

Ortiz, G.I., S. Sugaya, Y. Sekozawa, H. Ito, K. Wada, and H. Gemma. 2005. Efficacy of 1methylcyclopropene (1-mcp) in prolonging the shelf-life of 'Rendaiji' persimmon fruits previously subjected to astringency removal treatment. J. Jpn. Soc. Hort. Sci. 74:248-254.

Ortiz, G.I., S. Sugaya, Y. Sekozawa, H. Ito, K. Wada, and H. Gemma. 2006. Expression of 1-aminocyclopropane-1-carboxylate synthase and 1-aminocyclopropane-1-carboxylate oxidase genes during ripening in 'Rendaiji' persimmon fruit. J. Jpn. Soc. Hort. Sci. 75:178-184.

Owino, W.O., R. Nakano, Y. Kubo, and A. Inaba. 2002. Differential regulation of genes encoding ethylene biosynthesis enzymes and ethylene response sensor ortholog during ripening and in response to wounding in avocados. J. Amer. Soc. Hort. Sci. 127:520-527.

Peiser, G. 1989. Effect of 2,5-norbornadiene upon ethylene biosynthesis in midclimacteric carnation flowers. Plant Physiol. 90:21-24.

Pelayo, C., E.V. de B. Vilas-Boas, M. Benichou, and A.A. Kader. 2003. Variability in responses of partially ripe bananas to 1-methylcyclopropene. Postharvest Biol. Technol. 28:75-85.

Perkins-Veazie, P.M., D.J. Huber, and J.K. Brecht. 1996. In vitro growth and ripening of strawberry fruit in the presence of ACC, STS or propylene. Ann. Appl. Biol. 128:105-116.

Porat, R., B. Weiss, L. Cohen, A. Daus, R. Goren, and D. Droby. 1999. Effects of ethylene and 1methylcyclopropene on the postharvest qualities of 'Shamouti' oranges. Postharvest Biol. Technol. 15:155-163.

Pre-Aymard, C., E. Fallik, A. Weksler, and S. Lurie. 2005. Sensory analysis and instrumental measurements of 'Anna' apples treated with 1methylcyclopropene. Postharvest Biol. Technol. 36:135-142.

Rhodes, M.J.C. 1980. The maturation and ripening of fruits. In: K. Thimann (ed.). Senescence in plants. CRC Press, Boca Raton, FL.

Rizzolo, A., P. Cambiaghi, M. Grassi, and P.E. Zerbini. 2005. Influence of 1-methylcyclopropene and storage atmosphere on changes in volatile compounds and fruit quality of conference pears. J. Agr. Food Chem. 53:9781-9789.

Saltveit, M.E. 2004. Effect of 1-methylcyclopropene on phenylpropanoid metabolism, the accumulation of phenolic compounds, and browning of whole and fresh-cut 'Iceberg' lettuce. Postharvest Biol. Technol. 34:75-80.

Salvador, A., L. Arnal, J.M. Carot, C.P. Carvalho, and J.M. Jabaloyes. 2006. Influence of different factors on firmness and color evolution during the storage of persimmon cv. 'Rojo Brillante'. J. Food Sci. 71:S169-S175.

Sane, V.A., A. Chourasia, and P. Nath. 2005. Softening in mango (Mangifera indica cv. Dashehari) is correlated with the expression of an early ethylene responsive, ripening related expansin gene, Miexpa1. Postharvest Biol. Technol. 38:223-230.

Serek, M., E.C. Sisler, and M.S. Reid. 1994. Novel gaseous ethylene binding inhibitor prevents ethylene effects in potted flowering plants. J. Amer. Soc. Hort. Sci. 119:1230-1233.

Sisler, E.C. 2006. The discovery and development of compounds counteracting ethylene at the receptor level. Biotechnol. Adv. 24:357-367.

Sisler, E.C., T. Alwan, R. Goren, M. Serek, and A Apelbaum. 2003. 1-substituted cyclopropenes: Effective blocking agents for ethylene action in plants. Plant Growth Reg. 40:223-228.

Sisler, E.C. and S.M. Blankenship. 1993. Diazocyclopentadiene (DACP), a light sensitive reagent for the ethylene receptor on plants. Plant Growth Regulat. 12:125-132.

Sisler, E.C., R. Goren, and M. Huberman. 1985. Effect of 2,5-norbornadiene on abscission and ethylene production in citrus leaf explants. Physiol. Plant. 63:114-120.

Sisler, E.C., M. Serek, K.A. Roh, and R. Goren. 2001. The effect of chemical structure on the antagonism by cyclopropenes of ethylene responses in banana. Plant Growth Reg. 33:107-110.

Smith, R., G. Seymour, and G.A. Tucker. 1989. Inhibition of cell wall degradation by silver (I) ions during ripening of tomato fruit. J. Plant Physiol. 134:514-516.

Tesniere, C., M. Pradal, A. El-Kereamy, L. Torregrosa, P. Chatelet, J.P. Roustan, and C. Chervin. 2004. Involvement of ethylene signalling in a non-climacteric fruit: New elements regarding the regulation of $\mathrm{ADH}$ expression in grapevine. J. Expt. Bot. 55:2235-2240.

Toivonen, P.M.A. and C.W. Lu. 2005. Studies on elevated temperature, short-term storage of 'Sunrise' summer apples using 1-MCP to maintain quality. J. Hort. Sci. Biotechnol. 80:439-446.

Trainotti, L., A. Pavanello, and G. Casadoro. 2005. Different ethylene receptors show an increased expression during the ripening of strawberries: Does such an increment imply a role for ethylene in the ripening of these non-climacteric fruits? J. Expt. Bot. 56:2037-2046.

Trainotti, L., D. Zanin, and G. Casadoro. 2003. A cell wall-oriented genomic approach reveals a new and unexpected complexity of the softening in peaches. J. Expt. Bot. 54:1821-1832.

Tucker, G.A. and C.J. Brady. 1987. Silver ions interrupt tomato fruit ripening. J. Plant Physiol. 127:159-164.

Veen, H. 1983. Silver thiosulphate: An experimental tool in plant science. Scientia Hortic. 20:211-224.

Veen, H. and S.C. van der Geijn. 1978. Mobility and ionic form of silver as related to the longevity of carnations. Planta 140:93-96.

Wang, B.G., W.B. Jiang, H.X. Liu, L. Lin, and J.H. Wang. 2006. Enhancing the post-harvest qualities of mango fruit by vacuum infiltration treatment with 1-methylcyclopropene. J. Hort. Sci. Biotechnol. 81:163-167.

Watkins, C.B. 2006. The use of 1-methylcyclopropene (1-MCP) on fruits and vegetables. Biotechnol. Adv. 24:389-409.

Watkins, C.B. and W.B. Miller. 2005. A summary of physiological processes or disorders in fruits, vegetables and ornamental products that are delayed or decreased, increased, or unaffected by application of 1-methylcyclopropene (1-MCP). 2006. <http://www.hort.cornell.edu/ $\mathrm{mcp} />$.

Watkins, C.B. and J.F. Nock. 2005. Effects of delays between harvest and 1-methylcyclopropene treatment, and temperature during treatment, on ripening of air-stored and controlledatmosphere-stored apples. HortScience 40: 2096-2101.

Weaver, R.J. and R. Montgomery. 1974. Effect of ethephon on coloration and maturation of wine grapes. Amer. J. Enol. Viticult. 25:39-41.

Wills, R.B.H., V.V.V. Ku, D. Shohet, and G.H. Kim. 1999. Importance of low ethylene levels to delay senescence of non-climacteric fruit and vegetables. Aust. J. Exp. Agr. 39:221-224.

Wills, R.B.H., M.A. Warton, and V.V.V. Ku. 2000. Ethylene levels associated with fruit and vegetables during marketing. Aust. J. Exp. Agr. 40:465-470.

Yokotani, N., S. Tamura, R. Nakano, A. Inaba, W.B. McGlasson, and Y. Kubo. 2004. Comparison of ethylene- and wound-induced responses in fruit of wild-type, rin and nor tomatoes. Postharvest Biol. Technol. 32:247252.

Zhang, M.J., Y.M. Jiang, W.B. Jiang, and X.J. Liu. 2006. Regulation of ethylene synthesis of harvested banana fruit by 1-methylcyclopropene. Food Technol. Biotechnol. 44:111-115. 